\title{
Pink Ribbon Day as the International Breast Cancer Awareness Campaign
}

\author{
Abhirama Swastyayana Dian Perdana \\ Department of Communication Studies \\ President University, Cikarang, Indonesia \\ Perdana.abhirama@president.ac.id
}

\begin{abstract}
Abstrak
Pada masa sekarang, dengan meledaknya New Media, lazim kita melihat kampanye dan gerakan yang bertujuan untuk meningkatkan kesadaran akan isu-isu hangat. Salah satu contoh kampanye viral adalah kampanye video 'ALS Ice Bucket Challenge' yang sangat terkenal, dan di dalamnya banyak terlibat para selebriti dan tokoh terkenal. Dalam kaitannya dengan kampanye dan gerakan, pada tanggal 1 Oktober, perhatian kita sering ditarik agar mengingat Hari Pita Merah Muda - Hari Kesadaran akan Kanker Payudara Sedunia. Tidak hanya itu, terdapat salah satu kampanye di media sosial yang sangat menarik perhatian khalayak dunia -Kampanye Stand Up to Cancer (SU2C) - yang utamanya menarik perhatian mereka yang dalam hidupnya terkena berbagai dampak dari penyakit kanker. Artikel ini membahas dan menganalisa kampanye SU2C dalam kaitannya dengan endorsmen selebriti agar kampanye tersebut memenuhi tujuannya. Kasus SU2C inidianalisis di dalam framework Circuit of Culture untuk memahami bagaimana teori kehumasan dan Celebrity Humanitarianism dapat memberikan informasi mengenai berbagai praktik kehumasan di dunia. Tidak hanya itu, melalui refleksi Circuit of Culture, artikel ini juga membahas lebih lanjut tentang kemungkinan bagaimana analisa kampanye SU2C dapat digunakan untuk mempengaruhi kampanye kesadaran akan kanker lainnya, terutama di Indonesia.
\end{abstract}

Kata kunci: New Media, Campaign, Circuit of Culture, Celebrity Humanitarianism

\begin{abstract}
Currently, with the booming of New Media, it is not uncommon to see causes and campaigns meant to raise awareness on certain issues. One of the all-time viral campaigns was 'ALS Ice Bucket Challenge' campaign videos performed by well-known celebrities. In relation to causes and campaigns, on the $1^{\text {st }}$ of October, our attention is drawn towards the Pink Ribbon Day - known as the International Breast Cancer Awareness Day. Not only that, there is currently an attention-getting Cancer Awareness campaign in many social media - Stand Up to Cancer (SU2C) Campaign - which has drawn the attention of those whose lives have been touched by the various devastating Cancer illnesses. This paper discusses and analyzes the SU2C campaigns in relation to its reliance on celebrity endorsement in achieving its purposes. The case of SU2C is analyzed within the framework of Circuit of Culture to analyze how the public relations theory and Celebrity Humanitarianism may inform the various practices of public relations in the world. Not only that, through the reflections in the Circuit of Culture, the paper also elaborates the possibilities of how the analysis of the SU2C campaign can be used to influence other cancer awareness campaigns, particularly in Indonesia.
\end{abstract}

Keywords: New Media, Campaign, Circuit of Culture, Celebrity Humanitarianism 
We are the world, we are the children

We are the ones who make a brighter day

So let's start giving

There's a choice we're making

We're saving our own lives

It's true we'll make a better day

Just you and me

-- We are the World, written by Lionel B. Richie, Jr. \& Michael Joe Jackson.

\section{Background}

Every one of us who was born or grew up in the 1980's may still remember the song which excerpt is presented above used in the 'USA for Africa' Campaign in 1985 (USA for Africa, 2014). The same website also reveals to those few who are not familiar to the song - titled We are the World - that the 'USA for Africa' campaign was one of the early campaigns initiated by or made use of Celebrities and artists who lent their talents and popularity to raise awareness on a particular issue. In current days, with the booming of New Media, particularly when I check on my tablet every morning and access the Social Media, it is not uncommon to see causes and campaigns meant to raise awareness on certain issues. Some of which are the recently viral 'ALS Ice Bucket Challenge' campaign videos performed by wellknown celebrities.

In relation to causes and campaigns, on the $1^{\text {st }}$ of October, our attention is drawn towards the Pink Ribbon Day - known as the International Breast Cancer Awareness Day (Pink Ribbon Inc/Pink Ribbon International, 1997-2011). Not only that, there is currently an attentiongetting Cancer Awareness campaign in many social media - dubbed as the Stand Up to Cancer (SU2C) Campaign - which has drawn the attention of those whose lives have been touched by the various devastating Cancer illnesses. Two known highly successful fundraising campaigns were held, one Telethon in the United States on the $5^{\text {th }}$ of September, 2014, and a Celebrity-crowded Concert in the United Kingdom on the $17^{\text {th }}$ of October, 2014 (Entertainment Industry Foundation, 2014a, 2014b).

As one of those who have got the experience of having family members fighting a tough and losing battle against cancer, in this paper I endeavour to discuss and analyze the case study of the $S U 2 C$ campaigns in relation to its reliance on celebrity endorsement in achieving its purposes. The case of $S U 2 C$ is analyzed within the framework of Circuit of Culture (Curtin $\&$ Gaither, 2005) to analyze how the public relations theory may inform the various practices of public relations in the world. Not only that, through the reflections in the Circuit of Culture, the paper also elaborates the possibilities of how the analysis of the $S U 2 C$ campaign can be used to influence the creation of similar cancer awareness campaigns, particularly in Indonesia. In addition, although this study may not seem relevant to the field of traditional 
International Relations, the framework of Circuit of Culture offers a shift of paradigm in the field of International Public Relations (Curtin \& Gaither, 2005).

The following sections begin with a brief overview of celebrity endorsement and Celebrity Humanitarianism (Kapoor, 2013) as I focus the limelight on Pierce Brosnan, one of the prominent celebrity endorser in the $S U 2 C$ campaign - whose emotional life story brings significant results to the campaign. I then continue to put forward the notion of Public Relations as cultural practices and the framework used in analyzing the case, which is the Circuit of Culture with its relevance concisely mentioned above. The analysis of the case is organized by following each of the moment and discussing the linkage in the circuit as influenced by the creators of the original Circuit of Culture (Gay, Hall, Janes, Mackay, \& Negus, 1997).

As the paper discusses the role and participation of celebrity in campaign to raise awareness against cancer, a brief overview on celebrity endorsement and celebrity humanitarianism is required. Rojek (2001, p.16) argues that celebrity provides as role model to targeted audience. He further contends that the presence of celebrity can draw the attention the audiences and affect their desire to spend or consume through their increased curiosity (Rojek, 2001, p.91). I found that this may work, especially when I reflect particularly through the raised awareness towards the conditions in Africa, when artists or celebrities in the music industry gathered to display their talents in singing a heartfelt song, We are the World. These celebrities, then, are able to gain the attention through their presence as promotional effort and increase the visibility of whatever cause they raise (L'Etang, 2008, p.220; Turner, 2004, p.124).

The acts of celebrities taking parts in causes to promote situations and raise awareness against issues related to humanity are dubbed as "Celebrity Humanitarianism"(Kapoor, 2013, pp.16). He criticized the acts, however, by claiming that the celebrities do close to nothing than only making profit out of the audience, by enforcing consumerism, and thus self-promoting their own image (Kapoor, 2013, p.1). He goes further to argue that the organizations behind the campaigns have actually done little to mend the situations that they are fighting against, and that they only meant to put on a white hat, to raise their own status as also a celebrity (Kapoor, 2013, p.112). Despite that it may be true, to a certain extent, this paper displays the interplay and the reflections of what and how of Celebrity Humanitarianism - particularly in the campaign against cancer - within the circuit of culture. In addition, how the practice may be applied to inform other practices in Indonesia.

\section{Public Relations as Cultural Practices and the 'Circuit of Culture'}

The stage to be examined in this paper is $S U 2 C$, a campaign initiated by a fund-raising organization. Kelly (1991, cited in Domino \& Holtzhausen, 2004, p.41) maintains that it is more effective to discuss fund raising in the context of public relations, particularly when the fund raising involves celebrity endorsement. To address this, Curtin and Gaither (2005, p.93) propose that public relations need to be seen from the perspective of cultural form. In order 
to understand public relations as cultural practices, they draw on the work of du Gay et al. (1997, pp.3-5), the Circuit of Culture (Figure 1).

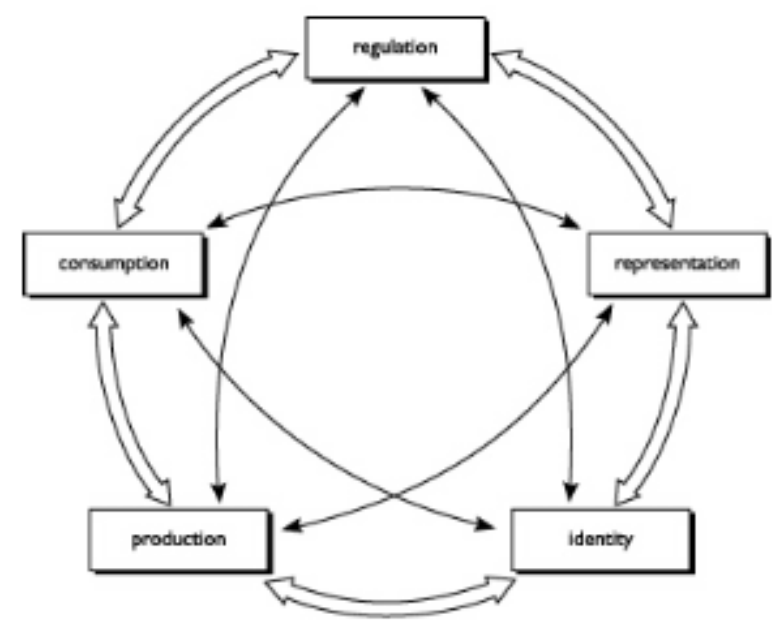

Figure 1 The Circuit of Culture (from Curtin \& Gaither, 2005, p.98)

Curtin and Gaither (2005, p.97) contends that public relations is a "cultural practice of meaning making." To understand this, it is paramount to first comprehend "...how social meaning is produced and reproduced in the different spaces of the circuit [of culture] (Gaither \& Curtin, 2008, p.288)." They argue that the circuit of culture allows for public relations practitioners to apply it in cross-cultural context and that it enables for practice to inform theory (Curtin \& Gaither, 2005, p.97; Gaither \& Curtin, 2008, p.282). Therefore, although the $S U 2 C$ campaign discussed in this paper is conducted in developed countries, it offers possibilities to be reflected and applied in other developing countries such as Indonesia.

The following sections elaborate and analyze the $S U 2 C$ campaign and the role of celebrity in this case, Pierce Brosnan -against the framework of circuit of culture discussed above. The SU2C campaign is then analyzed within each moment of the circuit: 1) regulation, 2) representation, 3) identity, 4) production, and 5) consumption(Curtin \& Gaither, 2005, p.98; Gaither \& Curtin, 2008, p.288). The paper follows the suggestion of Curtin and Gaither (2005) to separately examine each moment of the circuit as it allows

... (a) to gain an understanding of the dimensions of each moment, and (b) to demonstrate whether extant research fits into particular moments and suggests directions for future research(p.98).

Also, in order to guide the analysis of each moment in the circuit, the paper is informed by the practice matrix of the circuit of culture provided for both public relations practitioners and scholars in studying the case (Curtin \& Gaither, 2007, pp.217-221). The matrix helps by addressing the key considerations for each moment through "...situational factors, which are questions to be addressed in each moment..." and "...actions, which describe what a practitioner might do to guide activity in the moment (Curtin \& Gaither, 2007, p.227)." 


\section{Circuit of Culture: Reflecting from SU2CCampaigns and Pierce Brosnan}

Curtin and Gaither (2007, pp.225-226) suggest that although an exact starting point is not prescribed within the circuit of culture, having the moment of Regulation as the starting point beneficially assist public relations practitioners and scholar to understand the broad context of public relations culture before digging deeper into the moment in the circuit. Therefore, the following analysis begins with the moment of Regulation to better understand the environment of the SU2C campaigns. Then, the paper subsequently discusses each moment of the circuit of culture.

\section{Regulating Cancer Awareness}

Statistics reports show that Cancer has become one of the leading causes of death worldwide, standing as the first cause of death in the developed countries and the second cause in the developing countries(Jemal et al., 2011, p.69). In specific, they present that there are ...about 12.7 million cancer cases and 7.6 million cancer deaths are estimated to have occurred in 2008 worldwide ..., with $56 \%$ of the cases and $64 \%$ of the deaths in the economically developing world (Jemal et al., 2011, p.70).

The numbers show that the impact of cancer disease is so devastating that actions are required to be taken to tackle the issues. The numbers of cases have also prompted for governments of many developed countries to establish their own Cancer Research Foundations, the most notable ones are American Cancer Society, Cancer Research UK, and Cancer Australia(American Cancer Society, 2014; Cancer Australia, 2014; Cancer Research UK, 2014a).The websites of those Cancer Research and Foundations above also provide information that each of the mentioned countries has their own calendar of either international or local Cancer Awareness Days - one of which is the shared Cancer Awareness Month occurred on the $1^{\text {st }}$ of October of the year, worldwide. It shows that many Governments and societies share the needs to address the issue of Cancer that they need to regulate even the days for raising awareness as well as to tackle the disease through funding for cancer researches through the Foundations.

However, a quick browse on those Cancer Foundations' websites reveal that they still require certain budget to fund the cancer research, and therefore, they urge people and the website visitors to donate and create their own campaigns to raise fund (American Cancer Society, 2014; Cancer Australia, 2014; Cancer Research UK, 2014a). This is supported by the reports that many of these foundations are not financially supported by or receive limited budget from the government(Cancer Research UK, 2014b; National Cancer Institute, 2014).

The needs for funding, therefore, show that people or audiences' participation and proactive contribution is highly sought after. It also provides hints that these foundations require people or services to bridge the communication between the foundations and the audiences. The limited budget for cancer research, then, have spawned in the emergence of private organizations focusing on raising awareness towards cancer and collecting donations for cancer research through fund-raising campaigns. One of the previous successful cancer 
fundraising campaigns was the held in 2003, where Pierce Brosnan helped raised GBP 4 million for a local hospital in UK("Pierce Brosnan backs local UK campaign for cancer hospice," 2003). Another one was a US cancer awareness campaign where Pierce Brosnan was named the Ambassador of an annual event, the Lee National Denim Day - a breast cancer research organization - which successfully raised USD 8.6 million in 2005 and had raised more than USD 60 million from 1996 to 2006("Pierce Brosnan to promote Lee breast cancer fund raiser," 2006).

It shows that being supported by transparent regulations and the supports of the government, it is highly possible for fund-raising organizations to successfully contribute to the cause that it supports. The fact that the fame of Pierce Brosnan who back then was still having close ties to his movie persona, James Bond, managed to actively contribute to the campaign is also one of the reasons why he is chosen as the main object of study in this paper. In the following discussions on the moments in the circuit of culture, the role and history of Pierce Brosnan is further explored.

\section{The Production of Stand Up to Cancer (SU2C) Campaign}

In 2007, a group of women whose lives have been touched by cancer dedicate their effort to establish the SU2C campaign, which then is officially launched in 2008. Just recently, in the $5^{\text {th }}$ of September, 2014, SU2C held a Fundraising Telethon broadcast in the U.S. and Canada as well as a concert in the UK, on October 17, 2014. The SU2C Telethon and concert gathered selected celebrities and musician to share their life stories and experience against cancer, and perform their talent to raise awareness and more importantly fund for cancer research. By involving musicians, it shows that the campaign realizes that the power of music has become the "...most successful, entertainment vehicle for aggressively advocating social change (Sayre \& King, 2010, p.397).”

The telethon was a success as since its broadcast, SU2C has managed to garner more than USD 109 million of donation in the U.S. and Canada (Entertainment Industry Foundation, 2014b). The concert in UK has also reportedly been successful in garnering slightly over than GBP14.5 million (Entertainment Industry Foundation, 2014a). The use of Telethon format - a long duration television program used to collect donation - for the production may have been influenced by the knowledge that the average American spend up to 5 hours to watch television per day (Hinckley, 2014; "Television Watching Statistics," 2013).This fulfils that knowing the context of where a campaign is going to be held, the constraints and the availability of media to channel the content are exactly what the scopes of the moment of Production in the Circuit of Culture (Gaither \& Curtin, 2008, pp.290-291). The campaign itself strategically used the format of Telethon in the U.S. and Canada as it allows for the capture of captive attention -as the message was forcefully exposed to audiences through as they watch and interact to give donation (Davenport \& Beck, 2001, pp.22-23; Sayre \& King, 2010, p.145).

The SU2C Telethon also put the celebrities in the limelight to share their life experiences in battling cancer or having the life of their loved ones touched by cancer. One of the most 
widely covered story is Pierce Brosnan's, as he revealed that he had lost and witnessed the losing battle of his darling first wife and stepdaughter to ovarian cancer (Anon., 2014; Drohan, 2014; Oshmyansky, 2014; Radloff, 2014). The same magazine article also revealed that Pierce Brosnan is the celebrity figure appointed to announce that SU2C is

... putting together the first ovarian cancer dream team thanks to a joint collaboration with the Ovarian Cancer Research Foundation, the Ovarian Cancer National Alliance, and the National Ovarian Cancer Coalition(Anon., 2014; Drohan, 2014; Oshmyansky, 2014; Radloff, 2014).

It reveals that in the production of the campaign, the campaign organizer is aware that the selected celebrities participating and endorsing the cause of the campaign increase the visibility of the cause (L'Etang, 2008, p.220; Turner, 2004, p.124). The organizer also realizes that the emotional bond between the stories shared by the celebrities may increase the number of audiences as they can identify their struggles with the celebrities and make the celebrities as role-models (Rojek, 2001, pp.91-93).

\section{Representing the SU2C Campaign}

The moment of Representation in the context of the analyzed case of SU2C Campaign is related to the moment of Production. It has been discussed so far that the SU2C Campaign is meant to raise donation to fund cancer research Institution. From their use of campaign format and from the reasons why the celebrities are involved, it is known that the Campaign is meant to bridge the gap between the cause and the audience. In other words, it is meant for the audiences to relate and identify with the experiences of the celebrities. That they too can suffer from the disease and that they are willing do what they can to assist - by performing their talents and by donating - to 'stand up' against cancer.

For the audience not only to 'stand up' but also to act - to do something - against cancer is the encoded meaning that campaign organizers preferred for the audience to interpret(Hall and Morley cited in Hodkinson, 2011, pp.92-95; Kitzinger, 2004, pp.170-172; O'Shaughnessy \& Stadler, 2012, pp.102-103).The logo of the SU2C campaign itself, to represent the word up is actually using an upward arrow $(\uparrow$ ) instead up the initial ' $U$ ' (figure 2); and in the SU2C UK's website, three upward arrows is used (figure 3). Every sign such this arrow has a meaning and it consists of a "signifier and signified," according to Saussure (cited in O'Shaughnessy \& Stadler, 2012, p.132). In this context, the upward arrow may signify a sense of hope, to rise (together) against challenges. This is also the message that the Campaign like to convey, that all of us, not only the ones having the disease, rise together against common adversity called cancer. 


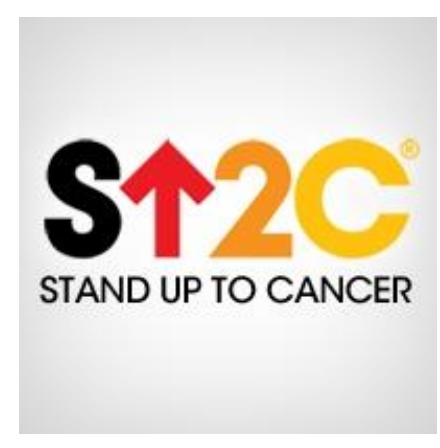

(Figure 2)

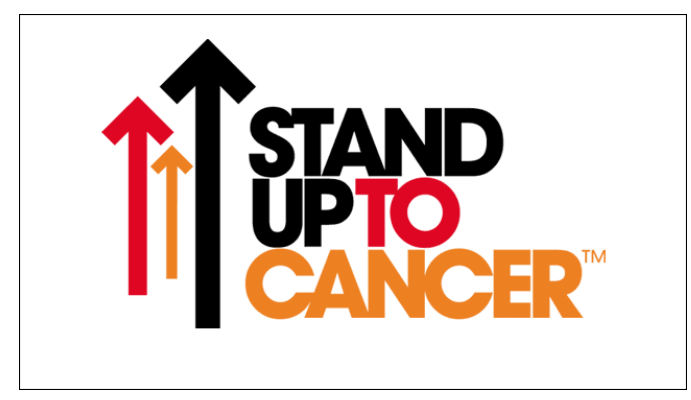

(Figure 3)

THIS IS WHERE THE END OF CANCER BEGINS

(Figure 4)

The tagline of the SU2C website, "This is where the end of cancer begins (with a diagonal arrow pointing at the content of the website - figure 4 above)," carries meaning the campaign is thoroughly serious in facing the issues of cancer and determines to end the problem. However, on the SU2C UK website, the tagline - "It's Pay Back Time" - may have dual interpretation. One is to exact revenge against cancer, to kill it once and for all. Another is for us audience, to act and donate some amount of money, to help fight against cancer.

\section{Consuming the SU2C Campaign}

Gaither and Curtin (2008, p.291) assert that the moments of Consumption and Production "...do not exist in binary opposition." The moment of consumption relates to the other moment as well. In this moment of consumption, the meaning produced by a Campaign is still incomplete without considering how the consumers or audiences make their own meaning out of what message is conveyed(Croteau \& Hoynes, 2003, p.266; Macdonald, 2003, p. 23). Therefore, to understand more on the meaning of a message, it is paramount to first understand how the audiences construct meaning "... as it completes the circle of text, production, and consumption (O'Shaughnessy \& Stadler, 2012, p.97).”

Based on the media coverage that primarily focuses on Pierce Brosnan's emotional speech at the Telethon and based on the considerable amount of donation, it can be concluded that Brosnan and the campaign has managed to win the attention of the audience and deliver the preferred meaning. As such, these audiences who are willing to support the campaign and donate for the campaign are categorized as Preferred Audiences (Hodkinson, 2011, p.93; O'Shaughnessy \& Stadler, 2012, p.102). The same category falls on those who showed up at the concert, stood up and made their donation for the campaign.

A quick browse at the user-friendly webpage of the SU2C campaign (Entertainment Industry Foundation, 2014a, 2014b), it is shown in the 'Get Involved' tab that there are many ways to participate in the campaign while also making direct donations. One link tab called "don't just stand there" suggests that there are possibilities for audience to only stand up, showing a sign of whom they are standing up for, without making any donation. This group of audience, who fulfill only part of what the message conveys are categorized as negotiated 
audiences (Hodkinson, 2011, p.93; O'Shaughnessy \& Stadler, 2012, p.102). In addition, although there is no valid evidence, one can safely predict that there are also those audiences who did not do anything to support the cause nor make any donation. These groups of audiences are the oppositional audiences (Hodkinson, 2011, p.93; O'Shaughnessy \& Stadler, 2012 , p.102), who rejects and not willing to fulfill the content of the message.

\section{The Identity of the People Involved in SU2C Campaign}

From the discussions in the moments of Representation, Production, and Consumption, the socially constructed meanings and practices in the campaign can be classified. It can be seen from the outcome of the campaign - not only from the images of the people showing support, but also from the amount of donation - that there are groups of people who care about the sufferings of those affected by cancer. From the (multiple) upward arrows used in the SU2C logo, it identifies that if a society stand together and act, beating cancer through breakthroughs in research is not impossible.

The identity position of the preferred audience discussed in the moment of Consumption serves as evidence to those affected by cancer, that there are still a sense of belonging of the members of family or a society through their sympathy and supports (Shotter, 1993). From the website and campaigns run by SU2C, it can also be seen that there is a group of people affected by cancer that identifies themselves as cancer survivors (Entertainment Industry Foundation, 2014a, 2014b). These survivors of cancer believe that they survive due to the supports of the people surrounding, supported by the feelings of not being alone.

\section{Conclusions and Recommendations}

By reflecting from the five moments, Public Relations practitioner and scholars may realize that there are aspects to be considered when preparing for a campaign. From the context of the Cancer Awareness Campaigns, the data from The World Health Organizations supports that although cancer "...is a leading cause of death worldwide, accounting for 8.2 million deaths in 2012 (World Health Organization, 2014)," the number of cases decline from that of 2008.It shows that given the fundraising campaign is well analyzed, it can make positive contribution.

The media coverage on Pierce Brosnan's emotional story of losing loved ones has triggered and set all things in motion ever since in 2003 including the amount of money garnered in the fund raising cancer awareness campaigns and the development in cancer research. This provides reflections for Public Relations practitioners worldwide that the use of celebrity can have enormous benefit through their high public profile which can often 'cut through communication noise and command immediate attention'.

The adoption of such use of celebrities may be applicable in a country such as Indonesia, where celebrities have become considered as role-models. However, the celebrities that are involved in a cause or campaign, needs to reflect the soul, and live out the story of the campaign itself to make sure of a better result. By having celebrities that share the story of the campaign, the audience can better relate to and identify the message of the campaign. 
The use of signs in the logo is also another area of consideration. From the Circuit of Culture - especially from the overlapping of the moments of Representation, Consumption, and Identity - it can be seen that the symbol of (multiple) upward pointing arrow(s) is an example how a group of people can share their sense of belonging in fighting a common enemy - the cancer disease. Therefore, reflections learned from the Circuit of Culture, can influence the practices of campaigns worldwide (such as Indonesia), if Public Relations practitioner are willing to use the framework of the circuit and analyze the moments appropriate to the context of the country location of the campaign.

\section{$\underline{\text { References }}$}

American Cancer Society, Inc. (2014). About Us. Retrieved October 24, 2014, from http://www.cancer.org/aboutus/index

Anon. (2014, September 09, 2014). Pierce Brosnan bravely opens up about losing both his wife and daughter to cancer, Hello! Retrieved from http://www.hellomagazine.com/celebrities/2014090920865/pierce-brosnan-talksabout-losing-wife-daughter-cancer/

Cancer Australia.(2014). About Us. Retrieved October 24, 2014, from http://canceraustralia.gov.au/about-us

Cancer Research UK. (2014a). About Us. Retrieved October 24, 2014, from http://www.cancerresearchuk.org/about-us

Cancer Research UK. (2014b). The Government's spending review - our reaction. Retrieved October 24, 2014, from http://scienceblog.cancerresearchuk.org/2013/06/26/the-governments-spendingreview-our-reaction/

Croteau, David, \&Hoynes, William. (2003). Media Society: Industries, Images, and Audiences (3rd ed.). Thousand Oaks: Pine Forge Press.

Curtin, Patricia A., \& Gaither, T. Kenn. (2005). Privileging Identity, Difference, and Power: The Circuit of Culture as a Basis for Public Relations Theory. Journal of Public Relations Research, 17(2), 91-115. doi: 10.1207/s1532754xjprr1702_3

Curtin, Patricia A., \& Gaither, T. Kenn. (2007). International Public Relations: Negotiating Culture, Identity, and Power. Thousand Oaks: SAGE Publications, Inc.

Davenport, Thomas H., \& Beck, John C. (2001).The Attention Economy: Understanding the New Currency of Business. Boston, Massachusetts: Harvard Business School Press.

Domino, Tracie, \&Holtzhausen, Derina.(2004). Toward an Integrated Communication Theory for Celebrity Endorsement in Fund Raising. Paper presented at the 7th 
International Public Relations Research Conference "Globalization: challenges and opportunities for public relations", South Miami Florida.

Drohan, Freya. (2014, September 08, 2014). Pierce Brosnan speaks out about losing family to cancer, Independent.IE. Retrieved from http://www.independent.ie/style/celebrity/celebrity-features/pierce-brosnan-speaksout-about-losing-family-to-cancer-30569850.html

Entertainment Industry Foundation. (2014a). Stand Up to Cancer: It's payback time. Retrieved October 24, 2014, from http://www.standuptocancer.org.uk/

Entertainment Industry Foundation. (2014b). Stand Up to Cancer: This is where the end of cancer begins. Retrieved October 18, 2014, from http://www.standup2cancer.org/

Gaither, T. Kenn, \& Curtin, Patricia A. (2008). International Public Relations: Toward an Integrated Theoretical Base. In T. L. Hansen-Horn \& B. D. Neff (Eds.), Public relations: from theory to practice (pp. 281-299). Boston: Pearson Education, Inc.

Gay, Paul du, Hall, Stuart, Janes, Linda, Mackay, Hugh, \& Negus, Keith. (1997). Doing Cultural Studies: The Story of the Sony Walkman. London: SAGE Publicatons.

Hinckley, David. (2014, March 5, 2014). Average American watches 5 hours of TV per day, report shows, New York Daily New. Retrieved from http://www.nydailynews.com/life-style/average-american-watches-5-hours-tv-day$\underline{\text { article-1.1711954 }}$

Hodkinson, Paul. (2011). Media, Culture, and Society: an introduction. London: SAGE Publications Ltd.

Hudson, Marian. (2009). Tactics. In J. Johnston \& C. Zawawi (Eds.), Public Relations: Theory and Practice (3rd ed., pp. 206-237). Crows Nest: Allen \&Unwin.

Jemal, Ahmedin, Bray, Freddie, Center, Melissa M., Ferlay, Jacques, Ward, Elizabeth, \& Forman, David.(2011). Global Cancer Statistics.CA: A Cancer Journal for Clinicians, 61(2), 69-90.

Kapoor, Ilan. (2013). Celebrity Humanitarianism: The ideology of global charity. New York: Routledge.

Kitzinger, Jenny. (2004). Audience and Readership Research. In J. D. H. Downing, D. McQuail, P. Schlesinger \& E. Wartella (Eds.), The SAGE Media Handbook of Media Studies (pp. 167-181). Thousand Oaks: SAGE Publications, Inc.

L'Etang, Jacquie. (2008). Public Relations: Concepts, Practice and Critique. London: SAGE Publication Ltd.

Macdonald, Myra. (2003). Exploring Media Discourse. London: Hodder\& Stoughton Educational. 
National Cancer Institute. (2014). Cancer Research Funding. Retrieved October 24, 2014, from http://www.cancer.gov/cancertopics/factsheet/NCI/research-funding

O'Shaughnessy, Michael, \&Stadler, Jane. (2012). Media and Society (5th ed.). South Melbourne: Oxford University Press.

Oshmyansky, Rosalyn. (2014, September 06, 2014). Pierce Brosnan 'Stands Up to Cancer', Entertainment Tonight. Retrieved from http://www.etonline.com/news/150845_pierce_brosnan_at_stand_up to_cancer/

Pierce Brosnan backs local UK campaign for cancer hospice. (2003). Retrieved October 24, 2014, from http://www.mi6-hq.com/news/index.php?itemid=980\&t=mi6\&s=news

Pierce Brosnan to promote Lee breast cancer fund raiser. (2006, July 12). Triad Business Journal.

Pink Ribbon Inc/Pink Ribbon International.(1997-2011). Pink Ribbon International. Retrieved October 24, 2014, from http://www.pinkribbon.org/

Radloff, Jessica. (2014, September 08, 2014). The 5 Most Inspiring Moments on the Red Carpet and Inside at Stand $\mathrm{Up}$ to Cancer, Glamour. Retrieved from http://www.glamour.com/entertainment/blogs/obsessed/2014/09/stand-up-to-cancer$\underline{\text { moments }}$

Rojek, Chris. (2001). Celebrity. London: Reaktion Books Ltd.

Sayre, Shay, \& King, Cynthia. (2010). Entertainment and Society: Influences, Impacts, and Innovations (2nd ed.). New York: Routledge.

Shotter, John. (1993). Cultural Politics of Everyday Life: Social Constructionism, Rhetoric and Knowing of the Third Kind. Buckingham: Open University Press.

Television Watching Statistics. (2013). Retrieved October 25, 2014, from http://www.statisticbrain.com/television-watching-statistics/

Turner, Graeme. (2004). Understanding Celebrity. London: Sage Publications Ltd.

USA for Africa.(2014). United Support of Artists for Africa. Retrieved October 24, 2014, from http://www.usaforafrica.org/We_Are_the_World/introduction.html

World Health Organization. (2014). Cancer: Fact sheet $N^{\circ} 297$. Retrieved October 24, 2014, from http://www.who.int/mediacentre/factsheets/fs297/en/ 